\title{
「光周波数コム光源デバイスの多様化」特集号によせて
}

\author{
田邊 孝純 \\ 慶應義塾大学 理工学部 電子工学科 ( ₹223-8522 神奈川県横浜市港北区日吉3-14-1)
}

\section{Preface to Special Issue on Increasing Diversity of Optical Frequency Comb Devices}

\author{
Takasumi TANABE
}

Faculty of Science and Technology, Keio University, 3-14-1 Hiyoshi, Kohoku-ku, Yokohama-shi, Kanagawa 223-8522

(Received December 22, 2017)

原子や分子の高分解能分光は, 光周波数の決定やスペ クトルの微細構造の決定等に不可欠であり, レーザーが 光源として用いられるようになって以来周波数精度が高 まり, 研究が飛躍的に進んできた。 その中でも, 光周波 数コム光源の開発は ${ }^{1-3)}$, 周波数基準光源, 超精密距離 計測や高精度分光応用などへ幅広い波及効果をもたらし ている．特に1990年代にTi:sapphireフェムト秒レーザー を用いた光周波数コム光源が開発され, その帯域や周波 数精度が飛躍的に改善した。 2000年にはキャリアエンベ ロープオフセット (Carrier Envelop Offset: CEO)が制御さ れるようになり ${ }^{4)}$, 光周波数コム光源の研究開発は隆盛 を極めるようになる.

このころから, Ti:sapphireレーザーに代表される大型 な固体レーザーに代わって，ファイバレーザーを用い た, よりコンパクトな光周波数コム光源の開発が行われ るようになっだ） その後こうした装置を用いてもCEO の制御や位相ノイズの低減が実現されるようになり, 光 周波数コム光源の多様化が進展した。

さらには, ファブリペロー共振器と電気光変調器 (Electro Optic Modulator: EOM) を用いたEOMコムや゙), 近年では微小光共振器での効率的な非線形光学効果を利 用して実現するマイクロコム ${ }^{7)}$ 等, 小型なデバイスを用 いて光周波数コムを発生させる研究が急速に進展し, 省 エネ, 小型で可搬性の高い光周波数コム光源開発の機運 が高まってきている.

本特集号では, 従来大型な固体レーザーが研究開発の 中心であった光周波数コム光源の, デバイス化の進展 や，それに伴って実現できる新たな応用展開にフォーカ スし，ファイバやデバイス型の光周波数コム光源に関連 する研究を, 国内の研究者に報告いただく.

初めに，稲場 肇氏に光周波数コムの基礎事項につい て大変丁寧に解説頂く，同氏は，ファイバレーザーを用 いた光周波数コムの先駆的なご研究をされている.ファ イバレーザーコムは小型な光周波数コム光源の中でも最 も高い周波数安定性を誇り, 応用研究も盛んである.
今回の特集号のテーマを理解するために必要な, 基礎的 な知識を得ることができるような, 大変すばらしい解説 論文となっている。具体的には, $\mathrm{CEO}$, 周波数信号の品 質評価に必要な位相雑音，アラン偏差，線幅の定義や測 定方法について，大変丁寧に解説されており，大学院生 を含む多くの読者を，当該分野にスムーズに導入するよ うな論文となっている。

次の論文が, 西澤 典彦氏らによるファイバレーザー を用いた中赤外光周波数コム光源の開発である. 中赤外 光は分子の指紋領域をカバーするので，センシング用途 で良く用いられる波長領域である。ファイバレーザーに よるコム光源の新しい展開として，当該光源を中赤外へ と波長帯域を拡大する試みが始まっているので, 当該研 究の最新状況について報告いただく.

光周波数コム光源を余すところなく活用するために は，その制御や測定技術の開発も，研究の両輪として進 める必要がある。そこで, 3 番目の解説論文は塩田 達俊 氏に光周波数コム光源を活用した, 超高速光波形計測と 分散計測応用について紹介いただく。

解説4では，デバイス色が高いEOMコムの最新研究に ついて石澤淳氏らに解説いたたく。 EOMを用いると $\mathrm{GHz}$ の高い繰り返しを有する光コムが得られる。また得 られた光コムの周波数を周波数安定光源に同期させて フィードバック制御することでマイクロ波発生器の雑音 を大幅に低減させることができるなど，興味深い応用が 紹介されている。

次の解説は小生による記事で, チップ集積できるとし て, 近年急速に注目が高まっている微小光共振器を用い たマイクロコムについて紹介した。 マイクロコムは，超 高繰り返し周波数光パルスが得られるという特徵があ る。この記事ではマイクロコム研究の海外の動向も含め て網羅的に紹介している.

その次の解説論文は, 同じくマイクロコム研究をされ ているSho Kasumie (霞江 翔) 氏らによる記事で, 光共振 器内の第三次高調波発生を利用して, 可視光のコムを発 
生した研究の紹介である.

最後に本特集号に関連したオリジナル論文として, 藤井瞬氏らの論文を掲載している。 ここでは, マイクロ コム研究で重要となる, 光コムの解析手法を紹介してい る. 特にLugiato-Lefever方程式と結合モード方程式の2つ の手法の比較検討が行われているが，詳細なモデリング の比較検討を行った論文は他には見当たらず，マイクロ コム研究のみならず非線形光学効果を考慮した共振器中 での光の振る舞いをモデリングしょうとしている研究者に とっては極めて有用な情報が含まれていると期待される.

本特集号を通じて光周波数コム光源の多様化が急速に 進んでいることを読者に皆さまにご理解いただき，国内 研究者の興味を喚起することで, 光源及びその応用研究 の活性化を促すきっかけとなることを願う。

\section{参考文献}

1) S. Diddams, D. Jones, J. Ye, S. Cundiff, J. Hall, J. Ranka, R. Windeler, R. Holzwarth, T. Udem, and T. Hänsch: Phys. Rev. Lett. 84 (2000) 5102.

2) R. Holzwarth, T. Udem, T. Hänsch, J. Knight, W. Wadsworth, and P. Russell: Phys. Rev. Lett. 85 (2000) 2264.

3) T. Udem, R. Holzwarth, and T. Hänsch: Nature 416 (2002) 233.

4) D. Jones, S. Diddams, J. Ranka, A. Stentz, R. Windeler, J. Hall, and S. Cundiff: Science 288 (2000) 635.

5) F.-L. Hong, K. Minoshima, A. Onae, H. Inaba, H. Takada, A. Hirai, H. Matsumoto, T. Sugiura, and M. Yoshida: Opt. Lett. 28 (2003) 1516.

6) 興梠元伸: レーザー研究 31 (2003) 438.

7) P. Del'Haye, A. Schliesser, O. Arcizet, T. Wilken, R. Holzwarth, and T. Kippenberg: Nature 450 (2007) 1214. 